Available online at: http://proceeding.rsfpress.com/index.php/ic-smart/index

Proceeding on International Conference of Science Management Art Research Technology

(IC-SMART)

Volume 1 Number 1 (2020): 146-150

\title{
Land Disputes Due to Two Certificate Title on the Same of Land in Indonesia
}

\section{Listyowati Sumanto}

Faculty of Law, Trisakti University, Jakarta, Indonesia

E-mail address: listyowati@trisakti.ac.id

\begin{abstract}
There are many land disputes, including cases of the certificate of title cancellation due to claims by other parties. The purpose of the research is to present an overview of the legal consequences if there are two land titles certificates on the same plot of land, causing legal uncertainty and uncertainty over land rights in Indonesia. This research uses the normative legal research method, descriptive, all of the data analyzed qualitatively. The resulting research that a certificate of title is a person's record of their land rights, which is issued by the National Land Agency to the person entitled to it. Certificate title has strong evidence of land rights regarding the physical and juridical data contained therein, as long as the data is in accordance with the data contained in the measurement letter and the land book (register) therein, which cannot be proven otherwise by other parties. Consequently, there are land disputes because there are two certificates on the same plot of land for several reasons. This research is restricted to land disputes on the certificate title to discuss. I argue that in the future, the National Land Agency should be responsible for changing its administrative management system. This research is limited to land disputes to the certificate title for discussion, and it is realized that it can be corrected in the future. This research contains research uniqueness.
\end{abstract}

Keywords: Land Disputes, Certificate Title

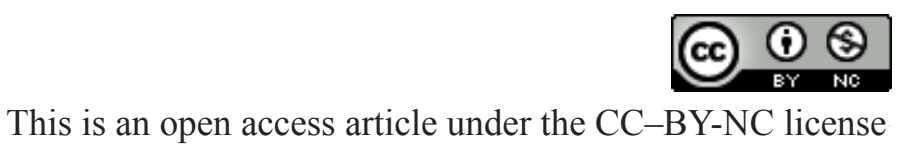

\section{INTRODUCTION}

The land is a natural production factor that is very important in fulfilling various needs. Therefore, it is necessary to guarantee legal certainty that is able to provide solutions for the concerned parties (Harsono, 2007). The fact is that until now, there are still many land disputes (Fitzpatrick, 1997). including the emergence of certificate cancellation cases due to claims by other parties. Issuance of certificates of the title is the final result of land registration, namely "recht cadaster" or legal cadastre (Harsono, 2013), which aims to provide legal protection and certainty to land rights owners (Sumardjono, 2000). A certificate of title consists of a copy of the land book and a measurement letter. The legal certainty and protection provided cover the status of the rights registered, subject, and object certainty. The owner of the certificate of title is not completely secure because there is no guarantee that the owner will not be sued by other parties. When a dispute occurs, the court will decide which evidence is correct. A certificate of title acts as strong evidence, but it is not the only evidence. Thus, the certificate of title is not absolute evidence. A certificate of title has functioned can provide strong evidence, safety, and peace for the landowners, a letter that provides certainty, and it can be accounted for before the law (Nae, 2013). This means that physical and juridical data contained in it have the power of evidence, and it must be accepted 
as true information as long as it cannot be proven otherwise. The state, in this case, does not absolutely guarantee the accuracy of physical and juridical data contained in the certificate of title. This is related to the publication system prevailing in Indonesia, namely the negative publication system, which contains a positive element.

\section{PURPOSE OF LAND REGISTRATION}

Fundamental land law in Indonesia is the Law No. 5 of 1960 concerning Basic Agrarian Law, has regulated land registration (Ginting, 2016), including the issuance of certificates of title (Edward, 1918). Land registration is a term Cadaster or record (Parlindungan, 1988). According to Article 3, Government Regulation No 24 of 1997 concerning Land Registration. According to Article 19 The Basic Agrarian Law and Article 32 paragraph (1) Government Regulation No. 24 of 1997, certificate of title is considered strong evidence of ownership, as long as the physical and juridical data are in accordance with data in the measurement letter and the land book (register) therein..

Based on land registration theory, there are two types of land registration consists of the registration of the deeds system and the registration of the titles system. There are also two types of publication systems consists of a negative publication system and a positive publication system. Basically, land registration with a negative publication system always uses registration of deeds system, and the state does not guarantee the correctness of the data presented in the register (Burns, 2011). Indonesia uses the registration of the titles system but uses the negative publication system, which contains a positive element.

In Indonesia, the weakness of using a negative publication system which contains positive elements is overcome by uses of customary law principles, namely "rechtsverwerking" (a person loses his land rights by expiration) to provide legal certainty for the parties who own land in good faith and they fulfill all land registration requirements (Laksamana. et al., 2018). Article 32 paragraph (2) Government Regulation Number 24 of 1997 regulates that a plot of land has a certificate of title under the name of a person or legal entity in good faith, and if within five years of the certificate issuance, the true owner does not file objections in writing to the certificate owner and the head of a land office or not to file a lawsuit through the court regarding the issuance of certificates of title, hence the true owner can no longer claim his rights, and he loses his rights. This provision is not always observed by the judges.

\section{METHODOLOGY}

The research method uses normative legal research (Yaqin, 2007), and data consists of secondary data obtained from library research. This research is descriptive, and the data were analyzed qualitatively (Marzuki, 2011) based on laws governing Land Registration. The research approach is a legal and conceptual approach (Hutchinson, 2002). In particular, this research is based on the analysis of legal norms, both of law in a legal sense as written in a book and law in the legal sense as decided by a judge through a judicial process (Dworkin, 1973).

\section{RESULT AND DISCUSSION}

Based on Bandung High Court Decision Number: 314/PDT/2019, there has been a buying and selling process of a $1090 \mathrm{~m} 2$ land with a Certificate of Ownership Title Number 762 in Jalaksana Village, Jalaksana Sub-District, Kuningan Regency, West Java Province, under the name of Haji Erneydi. In 2012, Haji Erneydi ordered his son (Hadi Kurnia) to sell a part of the aforementioned 
Proceeding on International Conference of Science Management Art Research Technology (IC-SMART),

Vol. 1 (1), 146-150

Land Disputes Due to Two Certificate Title on the Same of Land in Indonesia

Listyowati Sumanto

land to a couple of husband and wife, Rully Tirtayasa Simanjuntak and Yanti Aprianti, an area of 454 m2. On December 30, 2012, Hadi Kurnia passed away, followed by Haji Erneydi Supeno on March 28, 2013. In March 2018, Tati Hernati (wife of Hadi Kurnia) registered a transfer of rights on the land to the Kuningan Regency Land Agency. As mentioned before, in 2012, Hadi Kurnia sold a piece of the land as much as $454 \mathrm{~m} 2$ to Yanti Apriyanti based on a deed of sale and purchase Number 107/2012, which further used by Yanti Apriyanti to build a house and seven boarding houses along with a house belonging to Dani Ardiansyah with an area of $160 \mathrm{~m} 2$. However, in reality, Yanti Apriyanti has dominated and $1090 \mathrm{~m} 2$ of the total area. Because of that, Tati Hernawati visited the District Offices to ensure the validity of the Deed of Sale and Purchase Number 107/2012 of a piece of land with an area of $454 \mathrm{~m} 2$, which is further justified by the District Offices which stated that the deeds Number 107/2012 is valid. After that, Tati Hernawati filed a blocking on Certificate of Land Ownership Title Number 762 to the Regency Land Agency. Based on the land dispute, Kuningan Regency Land Agency, the blocking of Certificate of Land Ownership Title Number 762. This decision is in accordance with Article 30 paragraph (1) section C in the Government Regulation Number 24 the Year 1997 regarding Land Registration that mentions, "When a dispute on a land happens, the land certificate ownership must be suspended, and the dispute is noted in the land book". After that, Tati Hernawati filed a re-measurement order to Kuningan Regency Land Agency, but the agency informed her that the re-measurement order is only available when she withdraws the blocking of the certificate of title number 762 . This regulation is in accordance with Article 1 Number 1 of the Minister of Land and Spatial Planning/the Head of National Land Agency Number 13 the Year 2017 concerning Blocking and Confiscation Procedures, that mentions that: "Blocking record is an administrative action from the Head of Land Agency to establish temporary status quo (blocking) on the land-based on the legal action and legal event on the land." Article 3 mentions that: (1) "Blocking record is conducted on the land rights based on law action or law event, or because of the existence of a dispute or land conflict. (2) Blocking record is filed: (a) to provide law protection against the related land; and (b) At most 1 (one) time by 1 (one) applicant on 1 (one) land object. (3) The land book that records blocking of the land right unable to carry out land ownership data maintenance." In August 2018, after the Kuningan District Land Office carried out a re-measurement, the results turned out to be the fact that the location of the land with certificate No.1213 of $160 \mathrm{~m} 2$ owned by Dani Ardiansyah, is on the land of the Certificate of Ownership Title No.762 owned by Tati Hernawati. This means that on the same plot of land, there are two certificates under the names of different owners. The cause of the dispute over a double certificate was due to administrative errors or "administrative defects" by Kuningan Regency Land Office that does not carefully collect the physical and juridical data that resulted in "land rights overlapping." Article 107 paragraph (1) Regulation of the Minister of the Ministry Agrarian Affairs and Spatial Planning/the Head of the National Land Agency Number 9 of 1999, "Administrative defects consist of procedural errors, misapplication of laws and regulations, errors in subject and object of rights, errors in types of rights, errors in calculating the area of land, overlapping land rights and incorrect land legal and physical data".

The existence of a double certificate on the same land due to administrative, legal defects should enable the cancellation application of the certificate. In Article 1 number 14 Regulation of the Minister of the Ministry of Agrarian Affairs and Spatial Planning/the Head of National Land Agency Number 9 of 1999 concerning Procedures for granting and cancellation of rights to state land and management rights states that: "Cancellation of land rights is the annulment of decisions to grant land rights or land ownership certificate because the previous decision contains administrative, legal defects in its issuance or to enforce court decisions that have permanent legal force." Before the dispute goes to court (Abdurrahman, 2009), there are actually other efforts that can be taken first, namely by submitting a request for cancellation of land rights to the Land Office or the Ministry of Agrarian Affairs and Spatial Planning/National Land Agency, this is regulated in 
the Regulation of the Minister of Agrarian Affairs/the Head of National Land Agency Number 9 of 1999 Article 106 paragraph (1) in conjunction with Article 119 which states that "The decision to cancel land rights due to administrative, legal flaws in its issuance can be filed because of requests from interested parties or by authorized officials without a request." Cancellation of land rights due to administrative, legal defects is described by Article 106 of the Regulation of the State Minister for Agrarian Affairs/Head of the Ministry of Agrarian Affairs and Spatial Planning/National Land Agency Number 9 of 1999 concerning Procedures for Granting and Cancellation of Rights to State Land and Management Rights which reads: (1) The decision to cancel land rights due to administrative, legal defects in its issuance can be made because of requests from interested parties or by authorized officials without requests. (2) An application for cancellation of rights can be submitted directly to the designated ministries or officials or through the Head of the Land Agency.

This condition is caused by the carelessness of the National Land Agency or Regency/City Land Agency when they issue a certificate of title. Based on the complaints issued by disputing parties, National Land Agency will further examine the physical and juridical data in the certificate of title therein. Based on the Decree of the Head of the National Land Agency of the Republic of Indonesia No. 34 of 2007 concerning Technical Instructions for Handling and Solving Land Problems jo. Technical Guidance Number 08/JUKNIS/D. V/2007, the Head of Land Office has the authority to cancel one of the certificates. In principle, there are two basic reasons for the cancellation of land rights, namely: (1) The cancellation of the certificate is due to a court decision that has permanent legal force, and (2) The cancellation of the certificate is due to an administrative flaw in the issuance process.

The provisions concerning a certificate that was born first are a certificate that is strong or legally valid, the legal basis of which is contained in several Supreme Court Jurisprudence as follows: Supreme Court Decision No. 976K/Pdt/2015 dated 27 November 2015: "Whereas in assessing the validity of one of the 2 (two) authentic evidence of rights, the principle applies that the certificate of title issued earlier is valid and has legal force." In the land dispute case, which is the object of this research, in the High Court Decision Number 314/PDT/2019/PT.BDG, the judge decided to cancel the District Court's decision Number 14/Pdt.G/2018/Pn.Kng and won Yanti Aprianti as the owner of the entire land with an area of $1090 \mathrm{~m} 2$, which means that against a double certificate, the judge won the first certificate with Certificate Number No.762.

\section{CONCLUSION}

The cause of a double certificate of title on the same land is because it contains administrative defects or errors that result in overlapping land rights. This is due to the lack of accuracy and care in connection with the examination of juridical and physical data during the issuance of the certificate. The legal consequence of the existence of two certificates in the names of different owners on the same land is that the main objective of land registration is to provide certainty that rights for land rights owners have not been achieved. The National Land Agency should be responsible for changing its administrative management system.

\section{ACKNOWLEDGEMENT}

The author wishes to thank the Ministry of Agrarian Affairs and Spatial Planning/National Land Agency as a source of data for immense help to transform the data into this research, which we hope will be useful to its' readers. This work was supported by the Faculty of Law, Trisakti University. The author gratitude to ICSMART Conference International 2020 for making this publication happen. 


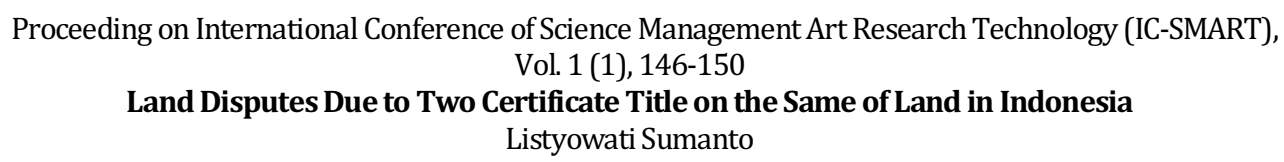

\section{REFERENCES}

Abdurrahman, 2009, "Settlement of Land Dispute". LMPDP-Land Journal Land Development Policy Media, pp. 2.

AP. Parlindungan, 1988, Land Registration and Conversion of Land Title According to Basic Agrarian Law, (Bandung, Alumni, 1988), pp.2

------. Indonesian Agrarian Law, History of Establishment of Basic Agrarian Laws, Content and Implementation, Jakarta: Universitas Trisakti, 2013, pp.71.

Burns, Fiona. "Adverse Possession and Title by Registration System in Australia and England", Melbourne University Law Review, vol. 35, pp. 777-779, 791-792, 2011.

Dworkin, Ronald, 1973, Legal Research (Daedalus: Spring, 1973), pp. 250.

Erp, Sjef van, 2017, “Land Registration Systems: Public, Private or Privately Public?", European Property Law Journal, vol. 6, no. 1, pp. 1-3.

Fitzpatrick, Daniel, 1997, "Disputes and Pluralism in Indonesian Land Law", Yale Journal of International Law, vol. 22, pp. 170.

Ginting, Darwin, 2016, "Land Registration in Information Technology Perspective a Basis of Basic Agrarian Law in Indonesia”, International Journal of Scientific \& Technology Research, vol. 5, no. 05 , pp. 185.

Harsono, Boedi, 2007, Towards the Improvement of National Land Law, (Jakarta: Penerbit Universitas Trisakti, Edisi 2007), pp. 4.

Hogg, James Edward, 1918, "Registration of Title to Land", Yale Law Journal, vol. 28, no. 1, pp. $51-58$.

Hutchinson, Terry, 2002, Researching and Writing in Law, New South Wales: Published Lawbook Co, pp. 35.

Laksamana, Rofiq, et.all, 2018, "Reconstruction Presumtion of Release Right on Land (Rechtsverwerking) in Land Registration in Indonesia", International Journal of Business Economics and Law, Vol. 16, Issue 5, August, pp.198.

Leks, Eddy, 2017, "Road to Legal Certainty Over Land Acquisition", The Jakarta Post, 10 Maret 2017.

Low, Rouhshi, Lynden Griggs, 2011, "Immediate Indefeasibility-is it Under Threat", Australian Property Law Journal, vol. 19, pp. 222.

Marzuki, Peter Mahmud, 2011, Legal Research, Jakarta: Publisher Kencana Prenada Media Group, pp. 133.

Massie, Eugene C. 1900. "The Torrens System of Land Registration and Transfer", the Virginia Law Register, vol. 6, no. 4, Aug., 1900.

Nae, Fandri Entiman, 2013, "Legal Certainty of Certified Land Rights Ownership", Jurnal Lex Privatum, Vol. I/No.5,2013), pp.62.

Sumardjono, Maria S.W., 2000, Land Law in Various Aspects, (Medan: Bina Media,2000), pp.36.

Yaqin, Anwarul, 2007, Legal Research and Writing. Malaysia: Malayan Law Journal SdnBhdLexisNexis. pp. 10. 